\title{
A Case of Adenocarcinoma of the Nasopharynx
}

\author{
Dong Kun Lee ${ }^{1}$, Heon Soo Park², and Jong-Chul Hong ${ }^{2}$ \\ ${ }^{1}$ Department of Otolaryngology-Head and Neck Surgery, Inje University College of Medicine, Busan Paik Hospital, Busan; and \\ ${ }^{2}$ Department of Otolaryngology-Head and Neck Surgery, Dong-A University College of Medicine, Busan, Korea
}

\begin{abstract}
비인두에 발생한 선암종 1예
이동근 ${ }^{1} \cdot$ 박헌수 $^{2} \cdot$ 홍종철 $^{2}$

인제대학교 의과대학 부산백병원 이비인후-두경부외과학교실, ${ }^{1}$ 동아대학교 의과대학 이비인후-두경부외과학교실 ${ }^{2}$
\end{abstract}

\author{
Received May 14, 2016 \\ Revised June 15, 2016 \\ Accepted June 16, 2016 \\ Address for correspondence \\ Jong Chul Hong, MD, PhD \\ Department of Otolaryngology- \\ Head and Neck Surgery, \\ Dong-A University \\ College of Medicine, \\ 26 Daesingongwon-ro, \\ Seo-gu, Busan 49201, Korea \\ Tel +82-51-240-5423 \\ Fax $+82-51-253-0712$ \\ E-mailssanta@dau.ac.kr
}

The major pathological type of the nasopharyngeal carcinoma is squamous cell carcinoma; on the other hand, adenocarcinoma of the nasopharynx is extremely rare. We report a case of a 68-year old male presenting a nasopharynx mass, which was revealed as adenocarcinoma, which could not be specified as any transoral tumor resection. Additional radiotherapy was applied. There is no evidence of recurrence during the seven years of follow-up.

Korean J Otorhinolaryngol-Head Neck Surg 2017;60(8):416-9

Key Words Adenocarcinoma $\cdot$ Nasal polyp $\cdot$ Nasopharynx.

\section{서 론}

비인두에 발생하는 원발 암종은 인구 10 만당 1 명 정도에서 발생하는 드문 질환으로, 주로 동남아시아, 중국 남서부에서 많이 보고되고 있다. ${ }^{1)}$ 주된 연령은 40 70대이며, 남자와 여 자의 비율은 2.3:1이다. ${ }^{2)}$

암종의 대부분은 상피세포 기원의 각질화(keratinizing) 또 는 비각질화(non-keratinizing) 편평세포암종(squamous cell)이며, 그 외 전체 비인두암의 $5 \%$ 이내에서 선암종(adenocarcinoma), 림프종(lymphoma), 육종(sarcomas) 등이 차 지한다. 그 중 선암종은 전체 비인두 암종의 $0.48 \%$ 정도로 매우 드물게 보고되고 있다. ${ }^{1)}$ 국내에서는 단 2 예의 증례 보고 가 있었으며, 모두 유두상 비인두 선암종이었다. ${ }^{3,4)}$ 최근 저자 들은 비인두에서 발생한 특수한 조직형으로는 분류할 수 없

This is an Open Access article distributed under the terms of the Creative Commons Attribution Non-Commercial License (http://creativecommons.org/licenses/by-nc/4.0) which permits unrestricted non-commercial use, distribution, and reproduction in any medium, provided the original work is properly cited.
는 선암종 1 예를 국내에서 최초로 보고하는 바이다.

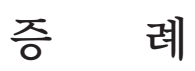

68세 남자 환자가 2008년 12월경 경부 이물감 및 적색 객담 을 주소로 지역 병원을 방문하여 촬영한 인두 자기공명영상 에서 우측 비인두 부위 종물이 관찰되어 본원으로 전원되었 다. 방문 당시 경부 불편감과 음성변화를 호소하고, 코막힘, 체중감소, 호흡곤란 그리고 시력장애 등의 증상은 보이지 않 았다. 과거력은 경도의 흡연력과 음주력이 있었으나 30년 전 부터 중단하였다. 이학적 검사상 경부 종물은 촉지되지 않았 으며, 양측 고막 및 외이도는 정상 소견을 보였고, 구강 및 후 두에도 특이소견을 보이지는 않았다. 비인두 내시경 검사상 우측 비인두에서 인두 후벽까지 자라있는 둥글고 단단해 보 이며, 혈관이 풍부해 보이는 $4 \mathrm{~cm}$ 크기의 종물이 관찰되었고, 인두 자기공명영상 검사상 $\mathrm{T} 2$ 강조영상에서 고신호, $\mathrm{T} 1$ 강조 영상에서 근육과 비슷한 신호, 조영증강 $\mathrm{T} 1$ 강조영상에서 비 
균등한 조영증가를 보이는 $4.5 \mathrm{~cm}$ 크기의 용종형 종괴가 관 찰되었고, 두개저 또는 부인두 공간으로 침범은 없으며, 비인 두에만 국한되어 있었으며 경부 전이는 관찰되지 않았다(Fig. 1). 외래에서 내시경하 조직검사를 시행한 결과는 이형성을 보이기는 하지만 악성세포는 발견되지 않았다. 임상적으로는 단순 낭종이나 폴립(polyp)의 모양이 아니며, 악성의 가능성 을 배제해 할 수 없어 병리적 진단을 위한 목적과, 구강 접근 법으로 절제가 가능할 것으로 생각되어 종물 제거를 시행하 기로 하였다.

전신 마취 하에 구강 접근법으로 연구개를 절개하여 종괴 를 충분히 노출시킨 후 절제술을 시행하였다(Fig. 2). 용종형 종괴는 $5 \mathrm{~cm}$ 정도 크기로 비인두에서 구인두까지 커져 있었
으며, 표면에는 출혈 소견과 섬유화, 낭성 변화가 관찰되었다. 종물의 절제 후 동결절편 검사상 선암종의 소견이 보였으며, 절제연 침범이 보였다. 육안상 안전 영역을 포함하여 추가 절 제를 시행하였으나 동결절편 검사에서 안전역이 확보되지 않 았다. 구강 접근법으로는 추가적인 절제를 더 할 수가 없어서, 수술 후 추가적인 항암방사선 치료를 계획하고 수술을 종료 하였다. 절제 후 점막의 결손 부위는 크지 않아 자연 치유하 도록 하였다. 조직병리학적 결과 특수한 조직형으로는 분류할 수 없는 선암종으로 확인되었으며, 구인두 부위에서만 절제연 에서 종양의 침범이 관찰되었다(Fig. 3).

병기 설정을 위해 복부 초음파, 위식도 내시경, 대장내시경, 컴퓨터단층촬영, 골주사 검사, 양전자 컴퓨터단층촬영 검사
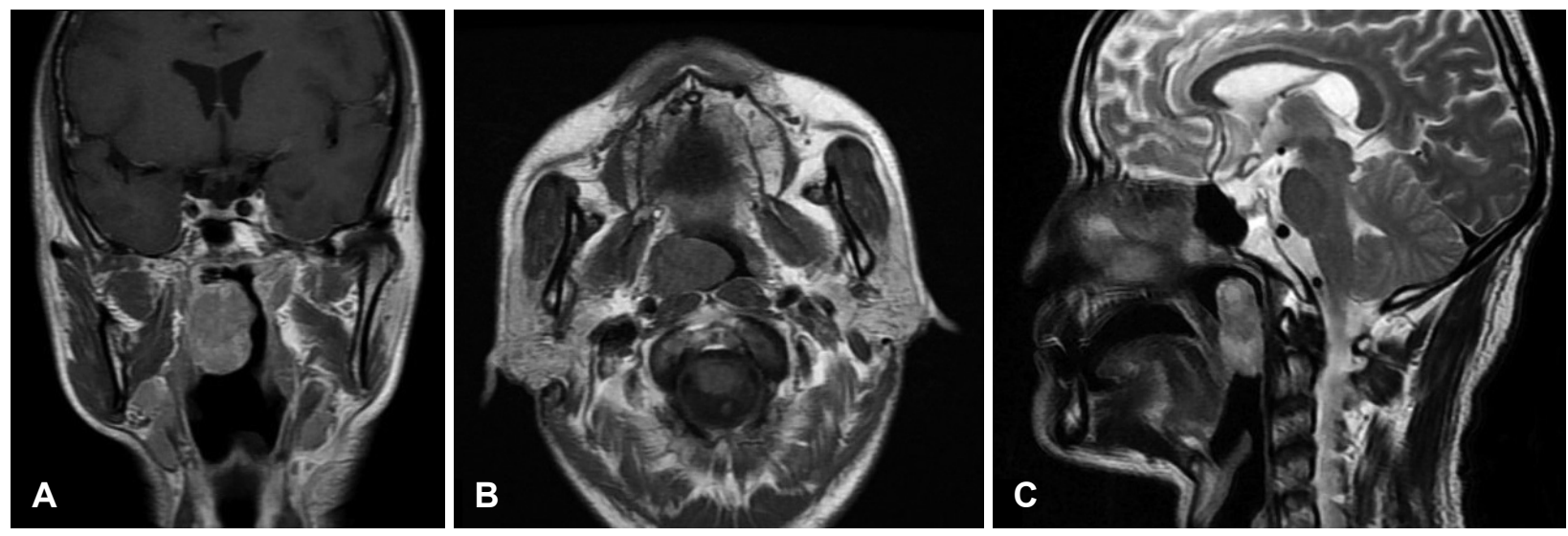

Fig. 1. Radiologic appearance of the nasopharyngeal andenocarcinoma (pharynx MRI images, A: gadolinium-enhanced T1 weighted image, B: T1 weighted image, C: T2 weighted image). A large lobulated inhomogeneous high signal polypoid mass is demonstrating at the nasopharynx.

Fig. 2. Preoperative image: a larger polypoid nasopharyngeal mass is showed after the soft palate retraction $(\mathrm{A})$. The mass excision via transoral approach. The mass was removed after the soft palate incision (B).

Fig. 3. Microscopic findings: the mass was composed of glandular structured tumor cells underneath relatively normal-looking squamous epithelium $(H \& E, \times 20)(A)$. On high magnification, covering squamous epithelium showed dysplastic change (black arrow) and invading tumor cells showed definitive glandular structure with mucin formation (white arrow) $(H \& E, \times 200)(B)$.
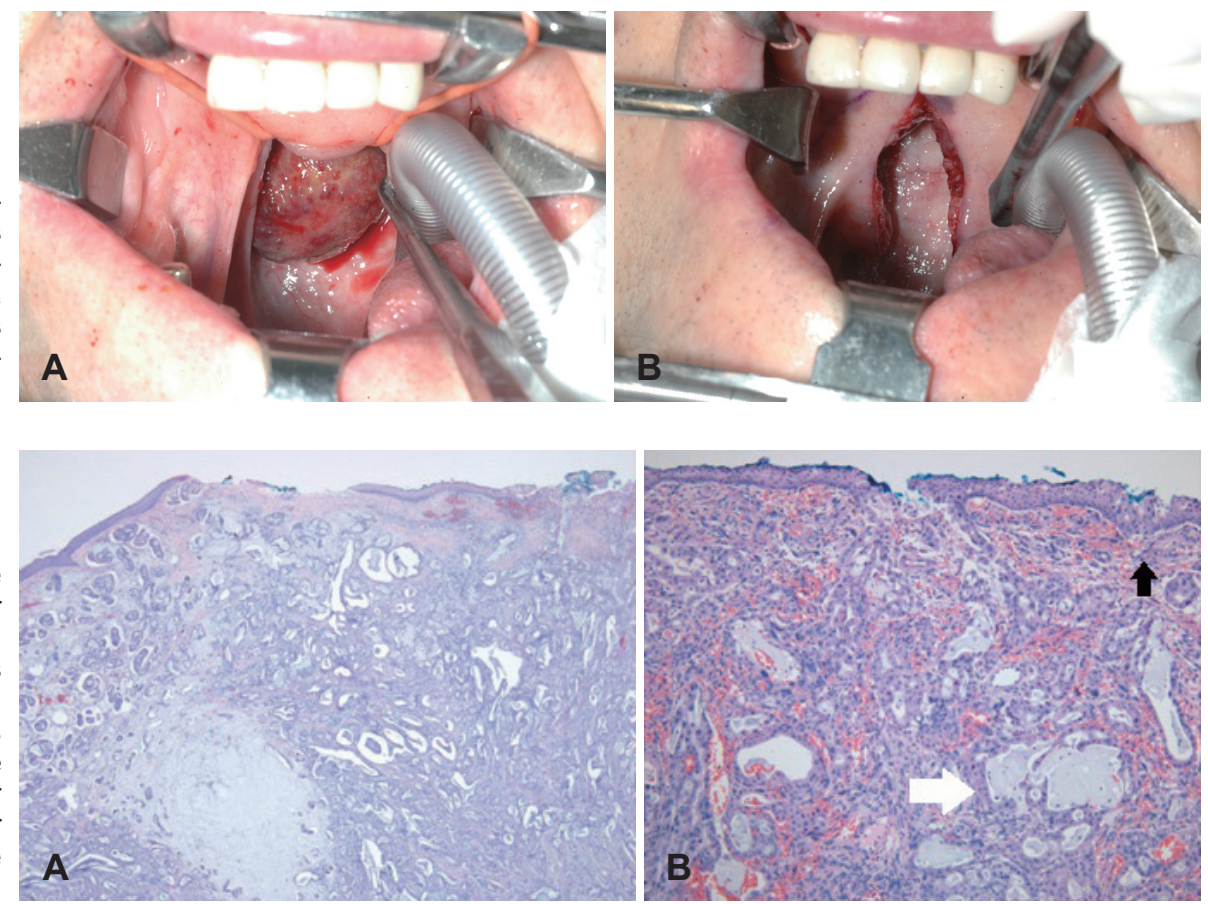
를 시행한 결과, 양전자 컴퓨터단층촬영에서 우측 구개수 부 위에 정중선을 넘는 대사증가 소견 이외에는 특이소견은 없 었다. 비인두에 발생한 선암종 pT2NOMO(Stage II)로 진단하 고, 환자는 수술 2주 후부터 $5760 \mathrm{cGy}$ 방사선 치료와 cisplatin 동시 항암방사선 치료를 받았고, 술 후 7년간 현재 외래 경과 관찰 중이며, 이학적 검사나 컴퓨터단층촬영에서 재발 의 소견은 관찰되지 않았다.

\section{고 찰}

비인두암 환자에서는 비인두와 경부에서 발견되는 종괴가 흔한 증상이며, 코막힘, 통증, 비출혈, 두통, 혈담 등의 증상도 나타난다. 임상적으로 국소적인 침범을 잘하며 경부 전이가 동반된 경우는 45 73\%까지 보고되고 있다. ${ }^{25,6)}$ 비인두에서 는 아주 드물게 선암종이 발생하기도 하는데 대부분 점막하 장액점액선(seromucinous gland)에서 기원하며 점액을 분비 하는 특성을 가지고 있다. 타액선 기원 암종의 종류에는 샘낭 암종(adenoid cystic type), 점막표피모양암종(mucoepidermoid carcinoma), 선암종이 흔하다. 비인두선암종은 병리학 적으로 일반형 (common type)과 침샘형(salivary gland type) 으로 나누어지며, 각각 $58 \%, 42 \%$ 를 차지한다. 일반형의 아형 으로는 조직형으로는 분류할 수 없는 형이 $48 \%$ 로 흔하며 그 외에, 유두상형(papillary type) 6\%, 샘꽈리세포형(acinic cell type) $2 \%$, 관형(tubular type) $2 \%$ 이며, 침샘형으로는 샘낭형 $29 \%$, 점막표피모양형 $10 \%$, 악성혼합형(malignant mixed type) $2 \%$ 로 보고된다. ${ }^{2)}$ Schramm과 Imola에 따르면 비인두 선암 종의 임상 증상은 일반적인 비인두암의 증상과 비슷하다. 뇌 신경 침범 증상이 $56 \%$ 정도로 일반적인 비인두암의 2 배였는 데, 이는 타액선 암종이 신경주위 침범이 흔한 것이 원인으로 생각되며, 삼차신경통이 가장 흔한 신경증상이었다.

가장 흔한 상피세포 기원의 비인두암은 방사선 치료에 반 응이 좋으며 항암방사선 치료가 일차적 치료이다. 방사선 치료 의 경우 평균 비인두 부위에는 $70 \mathrm{~Gy}$ 용량을 6 7주간 투여 하며, 경부에는 50 60 Gy를 5 6주간 투여한다. 저자의 사 례와 같은, 호흡소화관에 발생하는 소타액선 기원 암은 수술 적으로 접근 가능하다면, 수술적 절제와 추가 방사선 치료가 일반적으로 표준 치료방법으로 받아들여지고 있다. ${ }^{8-10)}$ 수술 적 접근법에 대해서는 아직 표준화된 접근 방법이 없다. 현재 는 상악골 회전 접근법이 두개, 안면의 심부를 잘 노출할 수 있기 때문에 주로 이용되고 있다. 하지만 이 접근법은 얼굴의 절개선이 필요하고, 부인두의 깊은 부위로 종양이 침범해 있 는 경우에는 노출이 좋지 않아서 대혈관 손상의 위험성이 있 다. ${ }^{11-13)}$ 한편 하측두와 접근법(infratemporal fossa approach)
이나 안와협골측(orbitozygomatic approach) 등의 측면부 접 근법은 상악골 회전 접근법에 비해 미용적으로 우수하고, 대 혈관을 조작하기가 쉬운 장점이 있는 반면, 반대편 비인두 노 출이 좋지 않고, 악하신경(mandiblular nerve)를 희생해야 하 는 단점이 있다. ${ }^{14)}$ 비인두는 해부학적으로 수술적 접근이 쉽 지 않지만, 유두상 선암종을 포함한 비인두 악성 종양의 비 내시경적 수술에 대해 보고한 Chen 등 ${ }^{15)}$ 에 따르면 종양이 비 인두에 국한된 경우나, 구인두 혹은 비강내로 침범은 있지만 부인두 공간 침범이 없는 $\mathrm{T} 1-\mathrm{T} 2$ 의 제한적인 경우는 내시경 적 치료로 6 명 중 5 명이 완치되었고 나머지 1 명은 수술 후 방 사선 치료로 완치되었다고 보호한 바가 있다. 비인두 선암종 을 48예를 수술 후 방사선 치료를 한 경우와 방사선 단독 치 료를 비교한 Guo 등의 의 연구에 따르면 조기 병변의 경우 수 술 후 방사선 치료를 한 경우가 방사선 단독 치료보다 국소 제어율(90\% 대 79\%)과, 5년 무병생존율(89\% 대 75\%)이 통 계적으로 유의하지 않았지만 다소 높은 경향을 보고하였다. 5 년 생존율은 48명 전체 환자들이 65\%이며, 조직유형에 따 라 일반형은 $63 \%$ 그리고 침샘형은 $69 \%$ 였다. 항암치료가 필 요할 때에는 cisplatin을 위주로 시행하며, 항암방사선 치료 를 병행할 경우 재발과 전이를 감소시키고, 생존율을 향상시 킬 수 있다.

비인두의 선암종은 매우 드물며, 국내에서는 단 2예의 사 례보고가 있었으며, 모두 유두상 비인두 선암종으로 저자의 사례와 같은 특수한 조직형으로는 분류할 수 없는 선암종은 보고된 바가 아직 없다. ${ }^{1,24}$ 저자들은 우연히 발견된 비인두 종괴가 내시경 조직검사상 악성 소견이 아니었지만 임상적으 로 악성을 의심하여 수술적 절제 생검을 시행하여 매우 드문 선암종을 발견할 수 있었다. 선암종과 같은 소타액선 기원의 암종은 조직검사 전에는 임상증상이 일반적 비인두암과 유 사하므로 구별하기가 어렵다. 림프절이나, 전신 전이는 없었 지만, 수술적 안전연을 확보하지 못하여 동시항암방사선 요법 을 시행하였고, 7년 동안 재발의 증거는 보이지 않았다. 비인두 에서 종괴를 발견하였을 때, 조직검사 소견에서 악성이 발견 되지 않았더라도 임상적으로 악성을 의심을 해보고, 드물지 만 선암종의 가능성도 고려해 볼 필요가 있다.

\section{REFERENCES}

1) Wei WI, Sham JS. Nasopharyngeal carcinoma. Lancet 2005;365 (9476):2041-54.

2) He JH, Zong YS, Luo RZ, Liang XM, Wu QL, Liang YJ. [Clinicopathological characteristics of primary nasopharyngeal adenocarcinoma]. Ai Zheng 2003;22(7):753-7.

3) Lee SJ, Chung PS, Lim ES, Kwon MS. A case of low-grade papillary adenocarcinoma of the nasopharynx. Korean J Otolaryngol-Head Neck Surg 2005;48(7):937-9.

4) Yang BW, Park MJ, Ahn BH. A case of nasopharyngeal papillary 
adenocarcinoma: nasal endoscopic approach. Korean J Otorhinolaryngol-Head Neck Surg 2011;54(6):423-6.

5) Guo ZM, Liu WW, He JH. A retrospective cohort study of nasopharyngeal adenocarcinoma: a rare histological type of nasopharyngeal cancer. Clin Otolaryngol 2009;34(4):322-7.

6) Abecasis J, Viana G, Pissarra C, Pereira T, Fonseca I, Soares J. Adenocarcinomas of the nasal cavity and paranasal sinuses: a clinicopathological and immunohistochemical study of 14 cases. Histopathology 2004;45(3):254-9.

7) Schramm VL Jr, Imola MJ. Management of nasopharyngeal salivary gland malignancy. Laryngoscope 2001;111(9):1533-44.

8) Garden AS, Weber RS, Ang KK, Morrison WH, Matre J, Peters LJ. Postoperative radiation therapy for malignant tumors of minor salivary glands. Outcome and patterns of failure. Cancer 1994;73 (10):2563-9.

9) Ellis ER, Million RR, Mendenhall WM, Parsons JT, Cassisi NJ. The use of radiation therapy in the management of minor salivary gland tumors. Int J Radiat Oncol Biol Phys 1988;15(3):613-7.
10) Spiro RH, Thaler HT, Hicks WF, Kher UA, Huvos AH, Strong EW. The importance of clinical staging of minor salivary gland carcinoma. Am J Surg 1991;162(4):330-6.

11) Chan JY. Surgical management of recurrent nasopharyngeal carcinoma. Oral Oncol 2014;50(10):913-7.

12) Wei WI, Chan JY, Ng RW, Ho WK. Surgical salvage of persistent or recurrent nasopharyngeal carcinoma with maxillary swing approach - Critical appraisal after 2 decades. Head Neck 2011;33 (7):969-75.

13) Chan JY, Chow VL, Tsang R, Wei WI. Nasopharyngectomy for locally advanced recurrent nasopharyngeal carcinoma: exploring the limits. Head Neck 2012;34(7):923-8.

14) Zhang M, Garvis W, Linder T, Fisch U. Update on the infratemporal fossa approaches to nasopharyngeal angiofibroma. Laryngoscope 1998;108(11 Pt 1):1717-23.

15) Chen MK, Lai JC, Chang CC, Liu MT. Minimally invasive endoscopic nasopharyngectomy in the treatment of recurrent T1-2a nasopharyngeal carcinoma. Laryngoscope 2007;117(5):894-6. 